\title{
Defining Economics in the Twenty First Century
}

\author{
Bhekuzulu Khumalo \\ Private Researcher, Toronto, Canada \\ Email: bhekuzulu.khumalo@gmail.com
}

Received June 4, 2012; revised July 2, 2012; accepted July 10, 2012

\begin{abstract}
Economics as a subject matter has been given a variety of definitions over the last 200 years, however all the definitions have a similar concept that they lean towards, a general principle one can say. The definitions are not wrong, this paper does not seek to prove that they are wrong, but only to show they where right for their time, a subject matter like economics, though studied over the centuries only formally became a discipline in its own right in the last two centuries, and as such is fairly young and as we know more there perhaps is a time to seek a definition for economics for the twenty first century. This paper seeks to give such a definition in light of the increased understanding of economics or at the least we have access to greater information concerning the discipline economics than say Adam Smith, Alfred Marshall or Hayek. Take the definition by Samuelson, "Economics is the study of how societies use scarce resources to produce valuable commodities and distribute them among different people", though correct, is the definition sufficient for the twenty first century and beyond, that is all this paper seeks to answer, for it is the definition of a discipline that guides the readers thoughts. The objective of this paper is to simply reaffirm the modern definition of what is economics given we know so much more than 100 years ago.
\end{abstract}

Keywords: Definition of Economics; Knowledge; Modern Definition; Choice; Scarcity

\section{Contemporary Definition of Economics}

In the first week of one beginning their readings in economics, they will be given a definition of economics. Pick up any text book for the beginning reader in economics, and in the first few pages one will be given a definition of economics. This done because without a definition, it is very difficult to understand the subject matter of what one will be reading. A definition is a road map so to speak. A definition, both for the beginning reader and the experienced reader, gives a subject matter direction and scope. $\mathrm{X}$ is defined as this, if one reads this then they are reading $X$. If something crucial is missing in the definition then it will not be studied, or it will be relegated to a lower position than it deserves, robbing the reader of a more fulfilling understanding of the subject matter.

Take the textbook "economics" written by Ronald M. Ayers and Robert A. Collinge [1]. They define economics as, giving two interpretations, the first, "Economics examines how to make choices well." They also say, "Economics studies the allocation of limited resources in response to unlimited wants." To say economics examines how to make choices well can be questioned due to the nature of society, what is making a choice well, does rationality come into it, what is a rational decision, are humans rational [2]? Milan Zafirovski of the University of North Texas would not wholly agree with the concept of rationality and wrote a compelling paper about the confusions that arise with the concept of rationality. As we will see on further reading of the paper, economics examines choices, good or bad, economics can not really say what a good or bad choice is, it can only demonstrate the outcome of choice, that is economics as a science.

When one looks at the definition of rational in the dictionary, we see the definition as "agreeable to reason; reasonable; sensible; a rational plan for economic development.” Immediately we are moving into ideology, what is a rational plan for economic development? One would get a different answer from different economists depending on their ideology, and political view point. For economics to ever fully be a science, it has to it be able to make a distinction between ideology and dealing strictly with the material, it can not ever answer questions of morality, that is not the purpose of science, a purpose of science is to try and measure phenomenon, and understand the property of phenomenon. Therefore to say that economics examines how to make choices well is vague, it would be better to say economics examines the results of choices made and builds up "models" and logical systems that answer as best as possible what will likely happen when a certain choice is made, when a certain path is taken, this is because what seems irrational to one, might very likely be rational to another.

Take the choice of going to war as an example. One 
can argue that a war right now is necessary for long term stability as the enemy will be fought now and eventual victory will lead to greater living standards in the future. Another can argue that it is a waste of resources, and even if there is eventual victory, other societies that have not wasted their resources on war but rather on means of production will in the long run be better able to encroach our markets. Whose view point is the rational view point. Victory in a war might lead to a vassal state that will allow the victor to take their resources and less than what is considered "market" value, this additional resource might very well boost the society to its previous position or even better. However all can argue in the manner they see fit. Empires are built by arms, arms collect tribute. Though some say a pen is mightier than the sword, a piece of paper can be burnt, ignored or shut out.

However when we look at the second statement from Ayers and Collinge, "economics studies the allocation of resources in response to unlimited wants”, a fairly neutral statement with no ideological input possible. An economist can say with no guilt for example to client A who wants to take action $\mathrm{X}$ in policy for country 2 that, "if you want to take action $\mathrm{X}$, I am not saying the choice is good or bad, however given the limited resources you will have to give up this, this and that." It can not be disputed that a pure economists merely studies the allocation of resources as will be reaffirmed later in this paper. By virtue that economics studies, according to the definition given by Ayers and Collinge, the allocation of resources, it follows by implication as all should understand after a few readings in economics that economics deals extensively as its foundations with opportunity costs. This definition is generally in the standard modern definition of economics as we shall see. It is generally in the standard form of the definition of economics but there are still some flaws.

It must be understood that the concept of unlimited wants is not a modern concept but originates from the Middle Ages in Europe and it can be disputed. Quoting from Agnes Heller's book, [3] the "Renaissance man", we see that this idea originated in the Middle Ages, "Machiavelli talks a great deal about the boundless of human needs and the impossibility of satisfying them, and about the source of 'eternal discontent'. What is more, even the opponents of Renaissance anthropology were unable to escape from the influence of its general truths. Colet recognized that the intellect strives after the infinite and cannot be satisfied, and that is why he wanted it restrained." It is interesting to note how after many sentences Heller continues, "The insatiability of human needs stands in a reciprocal relationship with the limitless potential for the development of human work (creativity). Not only does production (work) grow quantitatively, and needs along with it-needs are also transformed, and they expand; new branches of production are accompanied by new needs and vice versa." One can not argue with Heller. On another note, how comes billionaires with their insatiable wants do not purchase all the variety of goods that are available, this however is another argument for another discussion.

Take the textbook merely entitled "Economics" written by Paul Samuelson [4]. The 1992 edition defines economics the same as did the first edition back in 1948. Paul Samuelson however makes clear in the 1992 edition that there are many definitions of economics none really more right than another because they are so similar. Samuelson distils his definition of economics to a "...common theme. Economics is the study of how societies use scarce resources to produce valuable commodities and distribute them among people." There is very little difference between Paul Samuelson's definition and the second definition given by Ayers and Collinge, and the many other examples as cited by Samuelson in his 1992 edition of his textbook Economics.

Other economists have been more broad than Samuelson in their definitions of what economics is. This could be that they did not want the beginning reader of economics to get lost, so they most likely felt to include as much as possible. Take the definition given by Richard Lipsey [5], "Broadly defined modern economics concerns:

1) The allocation of a society's resources among alternative uses and the distribution of the society's output among individuals and groups at a point in time.

2) The ways in which allocation and distribution change over time; and

3) The efficiencies and inefficiencies of economic systems."

Lipsey covers all the definitions that most economics give, but only part 1) can be considered the true definition. 2) and 3) are not true definitions, just concepts for the beginning reader to grapple with so they understand presumably what they are about to spend a large part of their life trying to understand. Take definition 2) by Lipsey, "the ways in which allocation and distribution change over time is more a process of economics, one who specializes in say trends, economic history, or economic philosophy would be interested in studying the changes over time. The changes in allocation and distribution are largely ideological, a change in the social system, a change in the mode of production. When we look at the third definition, what is meant by efficiencies and inefficiencies in an economic system, more garbage, is that efficient or a sign of efficiency, the more the garbage the more it means people have, but it could also mean environmental degradation. Who is to say that the allocation of a resource that way or this way is more efficient, more economical, this is entering a moral dilemma, it is not the job of economics to enter into moral dilemmas. It is when econom- 
ics enters into moral dilemmas that it becomes a dismal science, but economists like every other human being are allowed to discuss issues of morality, indeed take a side in issues of morality, but in their reading, in their scientific writings, morality does not come into issue, it should not be an issue. In simplest form economics should answer the question if action A is taken, B will be the result. However from reading most contemporary journals, most economists have read economics for a reasonable time seem to understand this concept.

Why are all these definitions of economics similar, yet we must understand that the definition of economics was not always so sophisticated. Alfred Marshall at the end of the $19^{\text {th }}$ century, when economics as a discipline was not as sophisticated as today defined economics as [6], "the study of people in the ordinary business of life." True one can say that is what economists do, because what ever we do generally does have some economic implication, but it is ordinary for human beings to cut their nails, should economics study this, economics does not study sleeping, yet if we do not sleep we will not be able to perform economic functions, our brains will not be able to handle it. Alfred Marshall therefore was not wrong, his definition was opening the door to the modern definition of economics, but it was just not sophisticated enough for the twentieth century with the growth of economic knowledge, should then the definitions we have today be sophisticated enough for the twenty first century.

In point of fact, before Alfred Marshall, say in the time of Adam Smith, there was no such discipline as economics, people read political economy rather than what would today be considered economics. People in those read economics in conjunction with politics, and philosophy. The subject matter had not evolved enough to dispense with ideology [7]. "Originally, political economy meant the study of the conditions under which production was organized in the nation-states of the newly-born capitalist system." Therefore for those who read economics the definition has been changing over time, and this is expected because of the nature of the discipline, it is new as compared to say theological studies, mathematics, pure sciences of which mathematics is the basis. Without mathematics you can not truly have a science [6]. Jevons for example defined economics as "the mechanics of utility and self interest." Yet today we have a fairly standard definition, a core principle of economics that most readers and thinkers of economics adhere to. This definition can be found in contemporary dictionaries. Dictionary. com defines economics as "the science that deals with the production, distribution, and consumption of goods and services, or the material welfare of humankind."

The serious reader of economic history will of course know where this definition originates from, it emanates from the paper written by Lionel Robbins first written/ published in 1932 [8]. This paper was titled “An Essay on the Nature and significance of Economic Science”. This paper built itself up to the definition of economics and defended that definition. It must be understood to be a good economist, one needs not have read this paper, however, it helps in understanding economics in the modern context, modern being early twenty first century. Early on in the paper Lionel Robbins starts by saying, "Every act which involves time and scarce means for the achievement of one end involves the relinquishment of their use for the achievement of another, it has an economic aspect." It is clear that Robbins is discussing opportunity cost, he does this in order for those reading his paper understand what economics is, what it should be in any instance, in order to build a firm foundation for the definition that he will come up with. Lionel Robbins continues, “...So, too, is the political economy of war. The waging of war necessarily involves of the withdrawal of scarce goods and services from other uses, if it is to be satisfactorily achieved. It has therefore an economic aspect. The economist studies the disposal of scarce means." By telling us what an economist studies, Lionel Robbins is setting the reader up for the definition of economics which he does a few sentences later. "Economics is the science which studies human behavior as a relationship between ends and scarce means which have alternative uses." From this definition offered by Lionel Robbins springs the contemporary definition of economics though different economists right it differently, but they are all saying more or less what Lionel Robbins said back in 1932.

Lionel Robbins continues in the paper to justify the definition that he has just given, and make sure people understand the only way he feels that economics can truly be a science. "It follows that economics is entirely neutral between ends; that, in so far as the achievement of any end is dependent on scarce means, it is germane to the pre occupations of the economist...it should be clear therefore, that to speak of any end as being itself 'economic' is entirely misleading." This last statement from Robbins cements economics the discipline as a science. Yet to this day one will hear people who are considered, and consider themselves well read in economics talking of this being more economical than that, even in lay man's language it is wrong. Economics as a discipline does not deal with a decision being more economical than another decision, it did however in the $19^{\text {th }}$ and pre $19^{\text {th }}$ century era., it should not today, if and only if it is taken as a science, a process that Lionel Robbins obviously was hoping to aide by writing the paper he wrote.

"The economist is not concerned with ends as such. He is concerned with the way in which the attainment of ends is limited. The ends may be noble or they may be base. They may be 'material' or 'immaterial'-if ends can be so described. But if the attainment of one set of ends in- 
volves the sacrifice of others, then it has an economic aspect." This statement by Lionel Robbins is the basis of reading economics, to understand as scientifically as possible the implications of choice, of a choice given limited resources, otherwise one reads and discusses political economy rather than economics.

Understanding the foundations of the modern definition of economics, we can ask ourselves a certain question. Given Paul Samuelsson's definition of economics that, "that economics is the study of how societies use scarce resources to produce valuable commodities and distribute them among different people," this definition is in principle correct, as is the definition from the dictionary, however, given that we know more about the economic process, are these definitions sufficient?

\section{What Was Seen but Not Acted upon}

[6] "Quesnay had propounded a school of economics known as Physiocracy and devised a chart of the economy called a tableau economique. The tableau was truly a physicians insight: in contradistinction to the ideas of the day, which still held that wealth was the solid stuff of gold and silver, Quesnay insisted that wealth sprang from production and that it flowed through the nation...But the trouble with Physiocracy was that it insisted that only the agricultural classes produced true wealth and that the manufacturing and commercial classes merely altered its form in a sterile way...in describing the industrial sector as performing only a sterile manipulation, it failed to see that labor produced wealth wherever it performed, not just on the land.

To see that labor, not nature, was the source of 'value' was one of Adam Smith's greatest insights. Perhaps this was the consequence of having grown up in a country that bustled with trade, rather than in the overwhelmingly agricultural setting of France.” (Heilbroner).

Wealth obviously does not come from bullion, or fiat currency for that matter. Bullion and only has value because it can purchase something, with no production gold and silver have no claim on wealth. The physiocrats at the least understood that wealth comes from production. Man values what men has produced, man values what has a use to him, food, this must be cultivated, other goods must be manufactured, Adam Smith understood this more of course than the physiocrats. What comes from nature without men's actions has no monetary value. What are these actions, they can either be more physical or more mental, designing a manufacturing plant and equipment is more mental than physical, whilst packing the manufactured goods into boxes is more physical. Even the bullion that has been valued throughout history is not valued in the ground, man must act upon it to create bullion and coins.

Humans do not just act blindly when they act upon nature, labor does not just act blindly when they produce, they must know what they produce, they must know how to produce it. Humans need knowledge. One could sense by the way Quesnay and Adam Smith attributed value to labor, to human action that they could understand that it is knowledge, but because of the way knowledge was mystified in this time period, they could grasp it, but left it out, there was not enough theoretical foundation to discuss knowledge as a commodity, as the primary commodity that creates all other commodities.

Over half a century would pass after Adam Smith's classic book, "An Inquiry into the Nature and Causes of the Wealth of Nations", that an economist and philosopher would understand the power of knowledge in economics, that we must know how to before we can give anything value. This economist philosopher would be John Stuart Mill. It must be understood that Adam Smith in particular did not ignore knowledge, he just left it as a philosophical opening, knowledge was mystified, it was not materialized so to say. Knowledge was not looked at as it is, that something was something, the European philosophers at the time were engaged with separating knowledge from the mind. For example engaging in asking somebody does a falling tree make a noise if you are not there to hear it, such thoughts are totally removed from any scientific scrutiny, in fact taking knowledge in that sense it is impossible to make any scientific scrutiny of knowledge. For example in January 2010 there was a destructive earthquake in Haiti. If I did not see it in the media does it mean it never happened, it is nonsensical debate. It is because of such thoughts on knowledge that though people like Adam Smith, Quesnay could see it, the philosophy of the day meant they could not grasp it. Even to this day those who are bemused by knowledge, hope everybody else is bemused because they are.

John Stuart Mill seemingly was one of the first to publish and realize the power of knowledge. Knowledge has always been the primary commodity, however because change was slow, people then took knowledge for granted. It was the industrial revolution when change became fast that one could see the power of knowledge in action, it no longer was a mystery it was there for all to see, for those who wanted to see.

[9] "Of the features which characterize this progressive economical movement of civilized nations, that which first excites attention, through its intimate connexion with the phenomenon of production, is the perpetual, and so far as human foresight can extend, the unlimited, growth of man's power over nature. Our knowledge of the properties and laws of physical objects shows no sign of approaching its ultimate boundaries: it is advancing more rapidly, and in a greater number of directions at once, than in any previous age or generation, and affording such frequent glimpses of unexplored fields beyond, as to jus- 
tify the belief that our acquaintance with nature is still almost in its infancy. This increasing physical knowledge is now, too, more rapidly than at any former period, converted, by practical ingenuity, into physical power. The most marvelous of modern inventions, one which realizes the imaginary feats of the magician, not metaphorically but literally - the electro-magnetic telegraph-sprang into existence but a few years after the establishment of the scientific theory which it realizes and exemplifies." (Mill).

Clearly from reading the above quotation from Mill, we see a profound admiration for knowledge, and a clear understanding that it is knowledge that is creating the great transformation of Mill's time. Mill seemingly grasped the concept that the increasing knowledge base of the laws of existence, laws of the material, which he called physical knowledge is seemingly unlimited, and at his time humanity was just at its infancy in beginning to understand thess laws of the material [10]. It is only limited by the concept of konke, konke being a point were a society or being knows everything, where all knowledge becomes timeless because it is all in easy grasp, the knowledge is there. However one can go further and say Mill in the above quotation though not fully comprehending, understood that the more timeless knowledge becomes, simply the more society knows, the more likely the modes of production and living will change. Whatever else can be said about Mill the above quote illustrates of how advanced he was for his time, he understood the key element and according to him it is the element "...which first excites attention, ...” Though understanding knowledge and it's process seemingly more than other economists of his time, he did not need to call those that turned the laws of existence, what he termed physical knowledge, into useful products are not magicians, especially literally maybe metaphorically, they are just people who understood how to use those laws and create useful products for other human beings. Mill however must be credited with putting this information, this observation on paper.

Therefore, one can say with confidence that the likes of Quesnay, Smith, and Mill all understood, though obviously because of increased theoretical frame work, Mill understood more and all had it in the back of their mind that it is the quality to gather knowledge, innovation can only spring forth from knowledge, from understanding the laws of the material. It would however be a great mistake to suggest that Mill, Smith, Quesnay, Schumpeter understood knowledge in a scientific manner without mystifying it. Mill thought they where literal magicians. Even Hayek's paper on knowledge was far from a scientific enquiry into knowledge. That branch of economics that deals with knowledge as an economic science is knowledge economics.

There is a philosopher however who did first link knowledge and economics 2500 years ago. However he wrote in pros and verse. His name was Lao Tzu, he just had one sentence to say [11]. "The more skills the people have the further the novelties multiply." Straight to the point, skills are a direct result of applicable knowledge, the more knowledge, the more skills, the more goods will multiply, the more novelties will multiply. Today there are a variety of goods available in the world for those with money, more than any other time in history, and this increase in goods/ novelties seemingly will continue for the foreseeable future with glitches here and there. These novelties/goods increase because societies that produce them more or less follow the laws of knowledge, this again is for another discussion. However it must not be forgotten that Lao Tzu to most extent also mystified knowledge, but it is expected, it was 2500 years ago.

By the twentieth century the most original economists understood the power of knowledge and others where no longer afraid to take risks in discussing knowledge [12]. Veblen can easily be considered one of the most original minds in economics. "... what Veblen called a society's 'immaterial equipment'," [1915, 272] is far more valuable than the material equipment. In a passage about the California Indians, Veblen wrote that:

"The loss of the basket, digging stick, and mortar, simply as physical objects, would have signified little but the conceivable loss of the squaw's knowledge of the soil and the seasons, of food and fiber plants, and of mechanical expedients would have meant the present dispersal and starvation of the community.

With the right knowledge lost material equipment can be replaced. Without knowledge, we are incapable of producing anything. Moreover, without the knowledge of how to use them, the most advanced machines and equipment are useless." (McCormick).

Ken McCormick in the above quote is trying to alert the reader of how Veblen was ahead of his time in his economic thought. Veblen above is clearly putting knowledge on the pedestal that it belongs on. Without knowledge not only will the California Native Community starve but the whole world would starve. Not only are the most advanced machines and equipment useless without the knowledge to operate them, the most advanced machines and equipment need knowledge to create them.

Dale Neef in his book [13], "The Knowledge Economy" as recently as 1998 again misunderstood knowledge, taking knowledge as a new phenomenon in economics. Clearly Veblen in 1915 understood more than Dale Neef who thinks that "'the knowledge-based economy' describes the ever-increasing proportion of the nations GNP dedicated to computerization and high-technology electronics industries." The economy has always been based on knowledge, human survival has always been based on knowledge, something that the likes of Veblen understood, in another way the likes of Neef are again 
trying to mystify knowledge, it only started with the computer age, totally a wrong concept of knowledge. However, Neef seems to confuse himself when he says, "I define knowledge in terms of potentially observable behavior, as the ability of an individual or group of individuals to undertake, or to instruct or otherwise induce others to undertake, procedures resulting in predictable transformation of material objects." This clearly has been going on throughout history, therefore the knowledge economy can not just have arrived in the last 50 or even 300 years. Hence the emergence of Knowledge economics, a discipline that understands knowledge as a prime resource since mankind existed, not a new phenomenon. Only somebody who understands knowledge can understand that the law that governs addition is equal in terms of knowledge to the law that defines energy or motion, though one might put different economic value on each law, they are essentially equal, so called knowledge economy can not understand such a concept though widely promoted.

In his book "The Road to Serfdom” [14], Hayek said: "This interaction of individuals, possessing different knowledge and different views, is what constitutes the life of thought. The growth of reason is a social process based on the existence of such differences...” then Hayek goes into political thought. Hayek clearly understood the process of the knowledge process in society and why freedoms must be guaranteed. Hayek of course was mainly concerned with the encroachment of big government and used knowledge as a defense for greater freedoms on that score he was right, he understood the laws of knowledge though not laying them down in point form.

Earlier on in the book Hayek said [14], "The question is whether for this purpose it is better that the holder of coercive power should confine himself in general to creating conditions under which the knowledge and initiative of individuals is given the best scope so that they can plan successfully; or whether a rational utilization of our resources requires central direction and organization of all our activities according to some consciously constructed 'blueprint'." Again Hayek recognizes the power of knowledge, he is however not making a scientific analysis of knowledge but using the power of knowledge to make a case for greater freedoms.

\section{Towards a Twenty First Definition of Economic}

Paul Samuelson it can be recalled from earlier on in this paper defined economics as [4] "the study of how societies use Scarce resources to produce valuable commodities and distribute them among different people.” This definition is derived from the definition that Lionel Robbins so eloquently defended in his 1932 paper. Paul Samuelson's definition however is sufficient for the purposes of this paper.

Samuelson and other economists before understood that resources are scarce and that this must be included in the definition of economics so that the aspiring reader of economics will always have this fact in the back of their mind. As resources are scarce and by their nature usually have more than one use, the concept of opportunity cost, again well laid out by Lionel Robbins in his works entitled "An Essay on the Nature and Significance of Economic Science.” What is a resource? The answer might seem obvious but it is better to investigate and be as clear as possible what a resource is. We can easily understand land, labor, and capital as resources. However, these resources to be resources must be able to produce valuable commodities, either by working on another commodity or being worked upon. Humans for example work on the land to produce valuable commodities, yet both humans and the land are considered resources. Every commodity in part comes from the land, the other part is humans working on what comes from the land. By working on the land they are either cultivating it or extracting minerals from it, or using the land to place capital, creating plants, mills, factories all in order to create valuable commodities suitable for human demand. A television for example has plastics processed from crude oil, copper wires, glass, all these things though coming from nature, in nature they are not suitable for human consumption, they must be processed. All material comes from nature even the "man made" material must be processed from material occurring in nature, a man simply alters the material form.

Before humans can create or convert anything into a commodity they must first identify the material that can help convert something into a commodity [10]. For example, take sandy soil, this type of soil is of no use for humans to say cultivate plants. The human must be able to identify that this type of soil will not be a great resource. However, thick black soil is considered a premium resource for agricultural purposes, the human being must be able to identify that this type of soil is a premium agricultural resource. One can make another example, sand though a part of the land is usually not considered a natural resource, however, black soil, iron ore, crude oil, platinum. Copper and yttrium are considered natural resources. That is the reality of human existence, some materials are considered natural resources other materials are not, why is this? The answer is simple, some materials have use for human beings some materials have no use. Iron ore is considered a resource only because of the knowledge humanity possesses about the properties of iron. It is a question of knowledge.

Human beings of the era of sword and spears identified iron as a resource but did not value crude oil, they had no use for it, though the crude oil was still there under the ground. Crude oil has been under the ground for 
millions of years or billions depending on the theory one beliefs in about the formation of oil. There is the Western theory that oil is from dinosaurs and the Russian theory that oil is naturally occurring for billions of years just like one finds iron ore, and gold in nature, oil is according to this theory a part and parcel of the world, if it came from dinosaurs why it is not everywhere. This cold war debate is not part of this paper. However, the critical level of knowledge possessed by humans to see crude oil as a resource occurred very recently in human existence; recently considering that scientists believe homosapians originated some 200,000 years ago. Yttrium, like crude oil, has fairly recently becomed a new resource, yet, yttrium, like iron ore has been in the ground for billions of years. Humans only recently achieved the critical level of knowledge to see that yttrium can be a resource.

It should be clear now that it is human beings who identify a resource, they identify this resource through knowledge. What is not a resource today can very well be a valuable resource in the future because of the growing knowledge base. Therefore not all materials are resources, but all materials are potential resources that can be commodified, that is can be made into a commodity and commercialized because they have a use for mankind.

It follows that not all humans can be considered a resource, but all humans are a potential resource for a society. People are resources because of their abilities, and all ability over and above physical power comes from knowledge. Physical strength without knowledge of what to do is meaningless. Therefore not all humans are resources without the concept of knowledge been added, understanding this power of knowledge in economics, it follows that a twenty first definition of economics must point the reader of economics the necessity of identifying resources, just as a definition must point out resources are scarce.

That it is understood that it is knowledge that allows us to identify a resource and to commodify the material and understand that this process has always been going on leads one to reject the claims of Robert Heilbroner and Lester Thurow, who in their book [15] "Economics Explained", seem to believe that the knowledge worker is a new phenomenon. Knowledge has always been a key to the survival of human beings. One therefore needs to analyze knowledge as a commodity, then and only then would one understand knowledge in a scientific manner, understanding the properties of knowledge as one understands the properties of any other commodity like, tea, coffee or platinum. Then it is possible to understand the change in the mode of living is highly correlated with the knowledge base of a society. Change in mode of living being the evolving economy.

Understanding this, a twenty first definition of, using Paul Samuelson's definition as a guide will therefore read as: Economics is the study of how society's use knowledge to identify resources and use these scarce resources through knowledge to create commodities. This of course is not a final definition merely the first part of a contemporary definition.

Note at this point for some finding the definition above difficult to comprehend, the easiest way to comprehend knowledge as a commodity is to take and understand what Bertrand Russell meant by what he considered facts. Take the theory and expand on it then one can take knowledge as any other commodity where they can add knowledge and theoretically calculate bow much knowledge the world has. But the importance of this can only be understood if the definition of economics does not exclude knowledge, remembering that it is the definition of a discipline that guides out readings, writings and thoughts on that discipline.

To continue with the paper it is important to look at probably the most modern definition of economics at present. The definition can be found from the Vanderbilt University website, www.vanderbilt.edu. They it seems in association with the American Economic Association, give a simple and easy to comprehend definition; [16] "economics is the study of how people choose to use resources." Then they explain what they mean by resources, "Resources include the time and talent people have available, the land, buildings, equipment, and other tools on hand, and the knowledge of how to combine them to create useful products and services."

The definition of what a resource is from the Vanderbilt University is important because of two key elements, it includes the concept of time and knowledge. Both key concepts have a more meaningful understanding and appreciation of economics.

The definition from Vanderbilt University does however miss an imperative consideration. In their definition of what is a resource, they say rightly that, "...and the knowledge of how to combine them to create useful products and services." It is accurate to say knowledge is needed to combine resources to create useful products and services, but it is not enough. It is also knowledge itself that is used to identify and create resources, therefore, knowledge itself is the primary resource and catalyst in every process of the economic process. The best definition in of what resources are, that from Vanderbilt University is association with the American Economic Association, misses this crucial reasoning. Why is this so, land, which land, that takes knowledge to answer that question. The question of how can only be answered by accepting the answer knowledge. All equipment is created by knowledge, how to create it and how to use it takes knowledge. A building takes knowledge to build, the more complex the more knowledge input will be needed, the output for anybody who understands can at most be equal to the 
input, but usually less than the input, knowledge is usually less than the sum of its parts, that is just the way knowledge is.

Take the richest human, or even the richest nation at this point in time, they can not fly to Mars, or to the nearest star, why, because the resources have not yet been identified. The material is probably there, but humanity does not yet have the critical level of knowledge to identify the materials that could create resources for interplanetary travel at the moment, therefore that resource does not exist. Society can not demand or supply a resource that has not yet been identified by the human mind.

Comprehending these concepts, economics can accordingly be defined as: economics is the study of how humans use knowledge to identify resources and use these scarce resources to create, using knowledge, commodities and distribute them among people. What a resource is was given to us by Vanderbilt University and the American Economic association, "resources include the time and talent people have available, the land, buildings, equipment, and other tools on hand, and the knowledge of how to combine them to create useful products and services," there a few better definitions of what a resource is than this one.

From the on set the reader of economics will understand how important knowledge is. One can only hope from the above definition that the aspirant reader in economics will understand that resources are identified by the human mind before they become resources. Computer software is now such an important resource, identified by the human mind and turned into a commodity, now it is difficult to imagine a world without computer software. The aspirant reader will understand that it is knowledge that creates commodities, when they become well read economists they can advocate the importance of knowledge to a society to create better commodities in order to contribute to human society, humans generally prefer the better products for the same amount of money. The definition hopefully will lead to future societies that respect knowledge and it's laws. Knowledge being the very thing that allows societies to progress in a material sense.

This definition given above, because it acknowledges knowledge as the driving force of material progression, answers some of the critics of definitions of economics that are derived from Lionel Robbins, that of course includes the definition from Paul Samuelson, the main criticism it answers are those concerned that Lionel Robbins definition of economics is static. The above definition, (one must not forget that this definition is too a progression from Lionel Robbins' definition of economics and accepts the arguments from Lionel Robbins concerning what an economist is and studies), can not be static. The process of identifying resources is not static, there is an action involved, the action of identification, an action im- plies non static, an action implies change.

This definition could very well also fall into the criticism that it ignores ethical aspects, and rightly so. Economics should not delve into how humans should behave, for that one would need to read the many philosophers past and present, one could read a book on ethics, for if economics starts to deal with ethics, it falls into traps that it can not answer in any meaningful way. Economics must deal strictly with analyzing the results of policy, laying solid theoretical groundwork on analysis of commodities. It was explained above that Lionel Robbins said an economist can never talk of this or that action been economical, because what does economical mean. Take for example a horrid dictatorship, a society that closes itself from the outside world with what most would consider despicable poverty and human rights violations. But who is this policy uneconomical for, for the majority who are poor they can say it is uneconomical. But for the ruling elite the policies are very economical, immoral maybe, according to one's morals, but uneconomical, they would be making a lot of money. Slavery was very economical for slave owners, uneconomical for the slave. Subsidies are economical for some, uneconomical for others the economist can only point out that subsidies divert resources.

Lionel Robbins paper is very important and relevant to this day, economist is first and foremost one who deals with how resources that are normally scarce are distributed, an economist is not a linguist or language expert, is not a biology master, or a master of physics, an economist does not talk in a serious manner on things being economical.

Having discussed the definition how does it for example help with economic concerns of this day and age. How does one stimulate an economy for example? Looking back at the definition, it possibly guides one to think of introducing new knowledge, new commodities, introduction of new resources is not as easy. Introduction of new commodities begins the cycle over, people purchase what they already do not have. New energy, new transportation, new ways, all these stimulate new demand and in the long run as has been discussed by knowledge economists who discuss the behavior of knowledge in the short and long run, once there are new commodities, a new short run behavior of knowledge kicks off, introducing new commodities is definitely a sign that society has entered a different short term knowledge model.

What about the question of African aide and investment. Understanding that it is knowledge the main driver of economics, one can sum up the African problems as not respecting the laws of knowledge, the laws that allow the knowledge base to grow in a society, when knowledge is treated for what it is, the primary resource and primary commodity. Not just Africa but the other poor regions. However, the question of politics comes into play, the 
society must be willing politically and ideology to follow as much as possible the laws of knowledge. One must not forget that the Russians for example have tremendous amounts of knowledge, first people in space, first satellites, however they failed to put their knowledge into the market one could argue because of their political system they could not. Therefore having the knowledge without following all the laws of knowledge will not likely lead to a wealthier society. Returning to the question of Africa, Africa must understand that it is people who are the main resource, would platinum be a resource if the mind had not deemed it so, would oil for that matter, it is humans who identify resources and Africans must be allowed to identify resource and create commodities, not just in speech but in deed.

Take the question of international trade. At its basis it is just an exchange of knowledge, goods are the result of use knowledge, that is to say knowledge that has been transformed to meet the needs of humanity. Exchanging knowledge can not be a bad thing, international trade therefore should be encouraged, this way the knowledge base of humanity increases, as each society seeks knowledge and shares its knowledge in the market place. However this paper was merely written to encourage a more modern definition of economics in order to stimulate tomorrow's readers of economics.

\section{Application of Definition to Economic Thought}

Economics is the study of how humans use knowledge to identify resources and use these scarce resources to create, using knowledge, commodities and distribute them among people, this is the most appropriate definition given all the analysis in this paper. The applications should be clear from the above paragraphs, the seven paragraphs preceding. One immediately understands the concept of knowledge as been central to human material development. Governments then should understand that they must make societies free for people to use their knowledge, because it is their knowledge that is the primary resource, if they are not allowed to use their knowledge how society will progress. Governments cannot feed all the people, people given the freedom to use their knowledge will find ways to feed themselves.

When it comes to development economics, it will be clearly understood that economics is just economics, allow people to use their knowledge and in time society will develop, because people are allowed to use their knowledge. Billions of dollars have been poured into Africa, Latin America, and many smaller Asian countries yet there has been no progress. Yet if people are made free to use their knowledge, and seek to increase their knowledge they will find ways to survive and create goods and services. The key missing aspect was the understanding of the power of knowledge.

One can only admire Germany after the second world war. Germany was split into two countries, West Germany controlled by USA, Britain and France, and East Germany controlled by the then USSR. The two peoples are German and had similar knowledge, yet in the 1950's West Germany began rapid economic expansion that continued for decades, whilst East Germans economic expansion lasted for a few years immediately after world war 2. Why is this, when obviously after the war they both had equal knowledge? It is because the West German government relaxed controls on people's ability to use knowledge.

China's economic expansion since the visionary Deng Xiaoping is a direct result of allowing people to use their knowledge, to find ways to feed themselves rather than burdening the state with planning for minute details. This way China's knowledge has grown step by step, until now they are one of the three global space powers including Russia and the USA.

Understanding it is about knowledge, pouring billions of dollars into countries that do not adhere to the principles of knowledge is really a waste of money, that money will just disappear to know where. Knowledge is respecting that everything takes time, especially economic development, as knowledge is built upon knowledge, it however takes a great visionary like Deng Xiaoping, Konrad Adenauer, to get the process started, both understanding this is a long term plan for their peoples.

Having knowledge as such does not itself guarantee great economic success, it is allowing people to use their knowledge, Russia is a leader in many fields, yet as an economic force it is not where it should be, why, tis has to have something to do with allowing people to use their knowledge.

Take resource rich countries, for a most part all they do as extract resources and sell them. In most instances this countries are static in cases of scientific inquiry, understanding and appreciating knowledge could very well change their attitudes, that they can be more than just resource providers, they can participate at a deeper level in the global economy.

Maybe it is time to offer development aide to countries that free up their people to use their knowledge, otherwise it will be just the same, countries will just not develop.

Most importantly as we approach the understanding that we all share this earth, and we are all human beings, and that greater knowledge is for the benefit of all mankind, we will accept facts for being facts regardless of where those facts come from, we will depoliticize knowledge so to speak. This way human beings will all accept each other as just human beings with the capability for all to think. But then again this is a topic for political economy and philosophy rather than economics per se. 


\section{Towards Defining Knowledge Economics}

Returning to the definition of economics as explained above, "economics is the study of how humans use knowledge to identify resources and use these scarce resources to create, using knowledge, commodities and distribute them among people", we can now define what knowledge economics is. Knowledge economics is the study of knowledge the resource: the properties of this resource and how knowledge affects the mode of living. Knowledge economics does not yet have a JEL classification number, I propose, S, and S0 will be for the general category.

When somebody reads knowledge economics or tries to enhance it they understand from the onset that knowledge is the primary resource, they want to learn its properties and use these properties to make economic decisions. They also to be complete as knowledge economists want to understand how knowledge affects the material change, the changes in he modes of production and living caused by changing knowledge base.

This paper was written simply to determine a definition of economics relevant for the twenty first century, to give the aspirant reader in economics a clear road map. I am sure in my historical analysis I missed a lot of great thinkers on knowledge, two in particular comes to mind, Paul Romer. Romer was ahead of his time in his thoughts, and if in the mid 1980's there was a paper dealing with the properties of knowledge, the behavior of knowledge, a theory concerning how to count knowledge, Romer would have been profoundly more successful at including knowledge in an economic model that would have been widely accepted, the second is Porter whose influence can be felt in the paper, a reader of economics who understood that it is [17] competitive advantage that gives a nation the edge, and the competitive advantage mostly comes from knowledge; but for the purposes of this paper the main drivers of knowledge in economics have been included.

There are other works that have influenced this paper but not directly quoted of course, the works of [18] Dewer, [19] Warsh, two great works by Hayek but not directly quoted but very influential [20], "The Use of Knowledge in Society" and [21] Hayek on Hayek. Another influential thinker of this paper would be Dopfer and Potts with their works [22], "The general theory of economic evolution". This paper is a follow up of the research note written earlier with the same title [23], "Defining Economics in the Twenty First Century", and is influenced by past works by Bhekuzulu Khumalo namely [24] "The Variable Time, Crucial to Understanding Knowledge Economics”.

\section{Conclusion}

Economics is the study of how humans use knowledge to identify resources and use these scarce resources to cre- ate, using knowledge, commodities and distribute them among people. This is an appropriate definition of economics given how far the discipline has come. It includes in the definition the very important concept of scarcity, a problem that is central to economics. By including the concept of scarcity it does not seek to break with the past but to add to the past. It however includes the important concept of knowledge, this paper has spent a lot of effort showing the importance of knowledge. It is knowledge that identifies resources, thus making them commodities. It is crucial to understand this concept. In simplistic terms, economics is the study of how we use resources that human minds have identified, and we use our minds to create commodities and distribute them, distribution implies choice. Who are commodities been distributed to? Having knowledge understood as a key component of economics, the beginning reader in economics will always understand that materials are not resources unless the human being has identified them as a resource and thus commodifying the material.

\section{REFERENCES}

[1] R. M. Ayers and R. A. Collinge, "Economics; Explore and Study,” Pearson Education, Upper Saddle River, 2005.

[2] M. Zafirovski, "Human Rational Behavior and Economic Rationality,” Electronic Journal of Sociology, 2003. www.sociology.org

[3] A. Heller, "Renaissance Man,” Routledge and Kegan Paul, London, 1978.

[4] P. A. Samuelson and W. D. Nordhaus, "Economics," McGraw-Hill, New York, 1992.

[5] R. Lipsey and K. A. Chrystal, "Positive Economics," Oxford University Press, Oxford, 1995.

[6] R. Heilbroner, "The Worldly Philosophers: The Lives, Times and Ideas of the Great Economic Thinkers," Simon and Schuster, New York, 1980.

[7] www.search.com/reference/Political_economy

[8] L. Robbins, "An Essay on the Significance of Economic Science,” MacMillan and Co., London, 1945.

[9] J. S. Mill, "Principles of Political Economy Books 4 and 5,” Penguin Books, London, 1848.

[10] B. Khumalo, “The Fundamental Theory of Knowledge,” 2006. www.repec.org.

[11] L. Tzu, “Tao Te Ching,” Translated by D. C. Lau, Penguin Books, London, 1963.

[12] K. McCormick, "Veblen in Plain English,” Cambria Press, New York, 2006

[13] D. Neef, “The Knowledge Economy,” ButterworthHeinemann, Woburn, 1998.

[14] F. A. Hayek, “The Road to Serfdom,” Routledge, London, 1944.

[15] R. L. Heilbroner and L. Thurow, "Economics Explained," Touchstone, New York, 1982. 
[16] “What Is Economics,” 2010. Vanderbilt.edu

[17] M. Porter, “The Competitive Advantage of Nations,” Free Press, New York, 1990.

[18] J. Dewer, "Intelligence in the Modern World," Random House, New York, 1939.

[19] D. Warsh, "Knowledge and the Wealth of Nations; a Story of Economic Discovery,” W. W. Norton and Co., New York, 2006.

[20] F. A. Hayek, "The Use of Knowledge in Society,” American Economic Review, Vol. 35, No. 4, 1945, pp. 519-530.
[21] F. A. Hayek, “Hayek on Hayek,” University of Chicago Press, Chicago, 1994.

[22] K. Dopfer and J. Potts, "The General Theory of Economic Evolution,” Routledge, Abingdon, 2008.

[23] B. Khumalo, "Defining Economics in the Twenty First Century (Research Note)," International Advances in Economic Research, Vol. 18, No. 1, 2012, pp. 128-129.

[24] B. Khumalo, "The Variable Time: Crucial to Understanding Knowledge Economics," Icfai University Journal of Knowledge Management, Vol. 7, No. 1, 2009, pp. 34-67. 